staff for a large spectrograph of very advanced design, which it is hoped will be installed at the coudé focus very soon after the new reflector comes into operation.

\section{Biblical Botany at the Hebrew University}

STudy of the flowers of the Bible has just been introduced to the Hebrew University at Jerusalem as a subject for students, who are showing considerable enthusiasm for it. Coupled with biblical botany is the study of Jewish and Arab plant-lore. Dr. Ephraim Hareubani is the lecturer, and he brings to his task thirty years of research into the flowers and plants mentioned in holy scripts. Together with his wife, also a botanist, he has collected almost all the specimens named and, using Mrs. Hareubani's own methods of preservation, has placed the whole collection in the University's Museum of Biblical Botany. He has identified and classified all the plants of ancient Palestine, Syria and Babylon mentioned in the Bible, the Hebrew Talmud and later Jewish writings. A conspicuous feature of the Museum of Biblical Botany is the fresh-looking appearance of the permanent exhibits which, without pressing or bathing in liquids, seem as though they have just been plucked, and retain their original colour and greenness of stalk. They are displayed in their natural groups in sealed cupboards. Among the many curious plants may be mentioned a species of Capparis. This blooms, matures and dies in a single day, and, by the exercise of considerable patience and vigilance, Dr. Hareubani has been able to show it in a series of half-hourly stages of growth.

STUDY of botany on a scientific plane was first begun in Palestine by Dr. Alexander Eig, late director of the Department of Botany at the Hebrew University. His researches, from 1921 onwards, led him to Syria, Turkey, Kurdistan and the desert tracts, and he built up a comprehensive collection of Near Eastern flora. The Palestine plants he classified according to the geographical and climatological types of the world groups (the country comprises two different floral regions), and he published a remarkably detailed phytogeographic map of Palestine. According to Faba Turovlin, broadcasting from the Jerusalem wireless station, "by following Dr. Eig's observations on the subject, the character of any particular district in Palestine may often be learned from the study of its plants, and in some cases from the occurrence of a single plant only". There is now periodically published a Palestine Journal of Botany.

\section{Excavation of a Hill Fort in Sussex}

THE hill fort or camp at Mount Caburn, near Lewes, which is under excavation by the Brighton and Hove Archæological Society, continues to yield interesting results. The investigations have now revealed the character and constructional history of the ramparts in some detail. According to a report on recent work (The Times, August 25), excavations in the upper rampart show that, when first constructed, it was retained by a line of posts and a net palisade.
A channel in the chalk indicates the line of the palisade. The second stage of the outer rampart, which covered the final period of occupation of the camp, is indicated by the fact that the original rampart was reinforced by a mixture of chalk and black mould. Post holes show that the rampart was further strengthened by fresh timbering. On the south side of the gateway a long cut has shown that the inner ditch had been filled up by the slipping of the inner rampart. Occupation floors of huts are clearly evident. There is no trace of occupation during the neolithic period, but a small piece of bronze has been found.

\section{Archæology and the Unemployed at Oxford}

OxFord, like the Irish States (see NATURE of June 11, p. 1041), has made use of measures for the relief of unemployment to further archæological studies. Voluntary labour from the Oxford and Wales camps of the Universities Council for Unemployed Camps has carried out excavations on Farington Clump during two seasons, proving it to be the site of the Adulterine Castles raised by Robert of Glouces. ter against King Stephen. In 1937, excavations were begun on a Romano-British and early Saxon cemetery site at Frilford. Here, under the direction of Dr. L. H. Dudley Buxton, members of a camp near Eynsham, consisting of ninety men from South Wales and twenty-five university men, worked daily on the Romano-British area. They located six graves and established the northwestern limits of the cemetery. A hoard of thirty coins made it possible to date the site with some precision. The Saxon area is of special interest, as it is one of the sites, rare in Britain, which was in continuous occupation during the period of Saxon penetration. Excavations are being continued at Frilford and on a site in the north of England. The men, some of whom have been out of work for years, showed a ready response, both technically and intellectually, to archæological training, and their interest in the results was keen. The three weeks in camp produced a marked improvement in physique. Funds for the continuation of this work are urgently needed, especially as the applications from clubs for the unemployed are increasing. Contributions may be sent to the treasurer of the appeal, Mr. J. Kelly, 16 Charlbury Road, Oxford.

\section{Insulin Treatment of Diabetes}

Prof. Charles Best, of Toronto, delivered the twelfth Stephen Paget Memorial Lecture at the annual general meeting of the Research Defence Society on June 9 (The Fight against Disease, 26, No. 3 ; 1938). Prof. Best is the co-discoverer, with Prof. Banting, of the anti-diabetic substance known as 'insulin', now universally used for the treatment of the disease, and the subject of his lecture was "Insulin and Diabetes : The Present Position". The stages in the discovery and preparation of insulin were first outlined, and Prof. Best then deseribed recent modifications-protamine- and protamine-zine insulins-by the use of which the effect of the dose is prolonged. He next discussed the influence of insulin 